\title{
Febre catarral maligna em bezerra no distrito federal
}

Camila Osse de Souza, Marcel Batista dos Passos, Márcio Botelho de Castro, Denise Ferreira Caldeira, Érica Garcia de Araújo Pinto, Antonio Carlos Lopes Câmara, Cristiane da Silva Pereira, José Renato Junqueira Borges

Hospital Escola de Grandes Animais, Faculdade de Agronomia e Medicina Veterinária, Universidade de Brasília(UnB), Brasília, DF, Brasil

*Autor correspondente

e-mail: cristianepereira@unb.br

\section{Resumo}

A febre catarral maligna (FCM) é uma doença infecciosa viral, pansistêmica, frequentemente fatal e com ampla distribuição geográfica. A FCM afeta principalmente ruminantes domésticos e selvagens e é caracterizada por distúrbios cutâneos, digestivos, respiratórios e neurológicos. A doença é causada por um vírus do gênero Rhadinovirus, pertencente à família Gammaherpesvirinae. Até o momento foram identificados quatro tipos de vírus que causam FCM em animais, sendo a forma africana, produzida pela cepa Alcelaphine Herpesvírus 1, a forma ovino-associada (FCM-OA), produzida pelo herpesvírus ovino-2, um terceiro vírus que induz a FCM clássica no veado-de-cauda-branca (Odocoileus virginianus), além de um vírus endêmico em cabras domésticas atualmente denominado herpesvírus caprino-2>. No Brasil existem diversos relatos de FCM-OA. Assim, objetiva-se relatar um caso de FCM em bovino no Distrito Federal, Centro-Oeste do Brasil. Foi atendida uma bezerra de 10 meses de idade e histórico de criação conjunta com ovinos e outro bovino. Segundo informações, o animal foi encontrado no piquete em decúbito e deprimido, sendo encaminhado para o Hospital Escola de Grandes Animais da Universidade de Brasília, onde foi encaminhado imediatamente para a baia de isolamento. Ao exame clínico, a novilha estava em decúbito lateral, apática, febril $\left(39,7^{\circ} \mathrm{C}\right)$, com mucosas hiperêmicas, halo cinzento na junção corneoescleral, secreção nasal mucopurulenta, lesões ulcerativas na mucosa oral e vulvar, além de petéquias nas gengiva, palato mole, palato duro e língua. Os sintomas neurológicos incluíram estrabismo central, opistótono, hiperestesia e movimentos de pedalagem. A bioquímica sérica revelou hipoproteinemia $(5,4 \mathrm{~g} / \mathrm{dL}) \mathrm{com}$ hipoglobulinemia (2,2 g/dL). Devido a suspeita clínica de FCM e prognóstico ruim, a novilha foi submetida à eutanásia in extremis. Os achados macroscópicos incluíram petéquias multifocais na gengiva, palato mole e duro; hepatomegalia, edema na mucosa e submucosa do intestino; bexiga difusamente avermelhada com 
petéquias e equimoses multifocais; e traqueia com inúmeras petéquias. A histologia apresentou manguitos perivasculares difusos por todos os cortes do encéfalo e casos menigeais. Havia discreta tumefação e hiperplasia de células endoteliais e áreas multifocais com discreta proliferação de células da glia (gliose). A rete mirabile apresentou acentuado infiltrado expandindo difusamente o gânglio de Glasser, composto por acentuada quantidade de linfócitos e plasmócitos. Na rete mirabile havia acentuado infiltrado invadindo as túnicas média e adventícia, expandindo o interstício, composto por grande quantidade de linfócitos e plasmócitos. Os swabs coletados com secreções perivesiculares foram submetidos à PCR para detecção do vírus ectima contagioso, FCM, pseudovaríola e vaccínia bovina, com positividade apenas para o vírus da FCM. A confirmação diagnóstica do presente caso foi baseada nos dados epidemiológicos, sinais clínicos, lesões histológicas características da enfermidade e detecção molecular de DNA viral, confirmando a ocorrência da FCM no Distrito Federal. 